\title{
UTILIZAÇÃO DE IMPLANTES INCLINADOS NA REABILITAÇÃO DOS MAXILARES
}

A insuficiência óssea em altura caracteriza maxilas com perda dos dentes posteriores. Nesses casos, uma solução imediata utilizando implantes osseointegráveis pode não ser possível, havendo necessidade de procedimentos prévios que propiciem um aumento ósseo nessas regiões. A fim de solucionar os casos mais rapidamente existe a possibilidade da inclinação dos implantes posteriores de direção distal para mesial acompanhando a anatomia do seio maxilar, possibilitando, assim, o emprego de fixações mais longas e ancorando-as em região de maior quantidade e melhor qualidade óssea (VASCONCELLOS, 2003). Este trabalho tem o objetivo de apresentar o caso clínico da paciente que apresenta ausência dentária na arcada superior, com quantia óssea considerável em região anterior e altura óssea posterior insuficiente para a instalação de implantes. Foi realizado a instalação de 6 implantes na região anterior ao seio maxilar com inclinação dos implantes posteriores no sentido postero-anterior. A técnica apresentada permitiu a reabilitação oral sem a necessidade de enxertia óssea.

Palavras-chave: Implantes dentários; Osseointegração; Seio Maxilar 